\section{Propagation of Sweetgale, Rhodora, and Catberry by Stem Cuttings}

\author{
Bryan J. Peterson ${ }^{1}$, Gregory J.R. Melcher ${ }^{1}$, Ailish K. Scott ${ }^{1}$, \\ Rebecca A. Tkacs ${ }^{1}$, and Andrew J. Chase ${ }^{1}$
}

AdDitional INDEX wORDs. adventitious rooting, Ilex mucronata, K-IBA, Myrica gale, peatmoss, perlite, Rbododendron canadense

Summary. Sweetgale (Myrica gale), rhodora (Rbododendron canadense), and catberry (Ilex mucronata) are shrubs of eastern North America that may have potential for broader use in horticultural landscapes. Because information on their vegetative propagation is scarce, we conducted experiments over 2 years to evaluate the effects of cutting collection date, wounding, substrate composition, and the concentration of applied potassium salt of indole-3-butyric acid (K-IBA) on rooting of each species. In 2015, we collected cuttings of each species on three dates to obtain both softwood and semihardwood cuttings. Cuttings were unwounded or wounded with a razor blade, and treated by dipping into water containing K-IBA at concentrations ranging from 0 to $15,000 \mathrm{mg} \cdot \mathrm{L}^{-1}$, after which they were inserted into a substrate of 3:1 perlite:peat (by volume) and placed under intermittent mist. In 2016, semihardwood cuttings of each species were all wounded, treated with K-IBA from 0 to $15,000 \mathrm{mg} \cdot \mathrm{L}^{-1}$, and inserted into substrates of $100 \%, 75 \%$, or $50 \%$ perlite, with the remaining volume occupied by peat. In both years, the greatest percentage of sweetgale cuttings rooted when no K-IBA was applied. K-IBA application also reduced root ratings, root dry weights, and root lengths of sweetgale. For rhodora and catberry, maximal responses for all measures of rooting occurred when $\mathbf{5 0 0 0}$ to $15,000 \mathrm{mg} \cdot \mathrm{L}^{-1} \mathrm{~K}-\mathrm{IBA}$ was applied. We recommend that growers use no exogenous auxin to propagate sweetgale, and 5000 to $10,000 \mathrm{mg} \cdot \mathrm{L}^{-1} \mathrm{~K}-\mathrm{IBA}$ to propagate rhodora and catberry. Cuttings of all three species can be collected from softwood or semihardwood shoots. Finally, sweetgale can be rooted in perlite alone, whereas rhodora and catberry required the addition of peatmoss for satisfactory root development.

$\mathrm{H}$ orticulturists who design informal landscapes may broaden their plant palettes by selecting species indigenous to local floras. Many native, colony-forming shrubs might be useful for horticultural landscapes but are absent from the nursery industry. Three examples from

Received for publication 18 July 2019. Accepted for publication 15 Oct. 2019.

Published online 20 November 2019

${ }^{1}$ School of Food and Agriculture, University of Maine, 5722 Deering Hall, Orono, ME 04469

Maine Agricultural and Forest Experiment Station Publication Number 3712. This project was supported by the U.S. Department of Agriculture (USDA) National Institute of Food and Agriculture Hatch Projects \#ME021614 and \#ME021614 through the Maine Agricultural and Forest Experiment Station. We thank Bradly Libby and Darren Hayes for helpful assistance.

Any opinions, findings, conclusions, or recommendations expressed in this publication are those of the authors and do not necessarily reflect the views of the National Institute of Food and Agriculture or the USDA.

B.J.P. is the corresponding author. E-mail: bryan.j. peterson@maine.edu.

This is an open access article distributed under the CC BY-NC-ND license (https://creativecommons.org/ licenses/by-nc-nd/4.0/).

https://doi.org/10.21273/HORTTECH04464-19 northern climates of North America are sweetgale (Myrica gale), rhodora (Rhododendron canadense), and catberry (Ilex mucronata). Sweetgale is a short-statured and densely branched shrub with finely textured, fragrant foliage. Rhodora produces attractive pink to purple spring flowers followed by steely blue-green foliage held on a mound of stiff branches through summer before developing autumnal coloration in tones of rose, orange, and burgundy. Catberry develops attractive and densely branched canopies and produces distinctive matte red fruits on elongated pedicels in late summer.

Many native shrubs have proven amenable to asexual propagation (Cartabiano and Lubell, 2013) and could therefore be more widely produced in the industry, whereas others like eastern leatherwood (Dirca palustris) are recalcitrant and unlikely to reach even those consumers keenly interested in native plants (Norris, 2011). Recently, the prospects for greater commercialization of a popular native plant of the northeastern United States, sweetfern (Comptonia peregrina), have been increased by improved methods to propagate it commercially (Gardner et al., 2019; Lubell and Brand, 2011). Phenology is an important factor for some species, such as species of serviceberry (Amelanchier sp.), which may be propagated from softwood cuttings but are famously recalcitrant once terminal buds have set (Still and Zanon, 1991). Species also may respond differently to environmental factors like the concentration of applied auxin (Cartabiano and Lubell, 2013) or the physical composition of the rooting medium (Hayes and Peterson, 2019; Lubell and Brand, 2011).

The first steps to wider adoption of new plants for horticulture are to develop effective protocols for their propagation and identify niches they can fill in horticultural landscapes. To evaluate methods for the efficient propagation of sweetgale, rhodora, and catberry, we conducted experiments over 2 years on the effects of cutting collection date, substrate composition, wounding, and the concentration of applied potassium salt of K-IBA on rooting percentage and metrics of root system quality.

\section{Materials and methods}

Plant materials. We identified native populations of sweetgale, rhodora, and catberry from which to obtain softwood or semihardwood stem cuttings in both 2015 and 2016. Stem cuttings of sweetgale were collected from five vigorous, sexually mature plants growing naturally at a wet forest edge in Penobscot

\begin{tabular}{llll}
\hline $\begin{array}{l}\text { Units } \\
\begin{array}{l}\text { To convert U.S. to SI, } \\
\text { multiply by }\end{array}\end{array}$ & U.S. unit & SI unit & $\begin{array}{l}\text { To convert SI to U.S., } \\
\text { multiply by }\end{array}$ \\
\hline 2.54 & inch $(\mathrm{es})$ & $\mathrm{cm}$ & 0.3937 \\
25.4 & inch $(\mathrm{es})$ & $\mathrm{mm}$ & 0.0394 \\
28,350 & $\mathrm{oz}$ & $\mathrm{mg}$ & $3.5274 \times 10^{-5}$ \\
1 & $\mathrm{ppm}$ & $\mathrm{mg} \cdot \mathrm{L}^{-1}$ & 1 \\
$\left({ }^{\circ} \mathrm{F}-32\right) \div 1.8$ & ${ }^{\circ} \mathrm{F}$ & ${ }^{\circ} \mathrm{C}$ & $\left({ }^{\circ} \mathrm{C} \times 1.8\right)+32$
\end{tabular}


16 June 2015
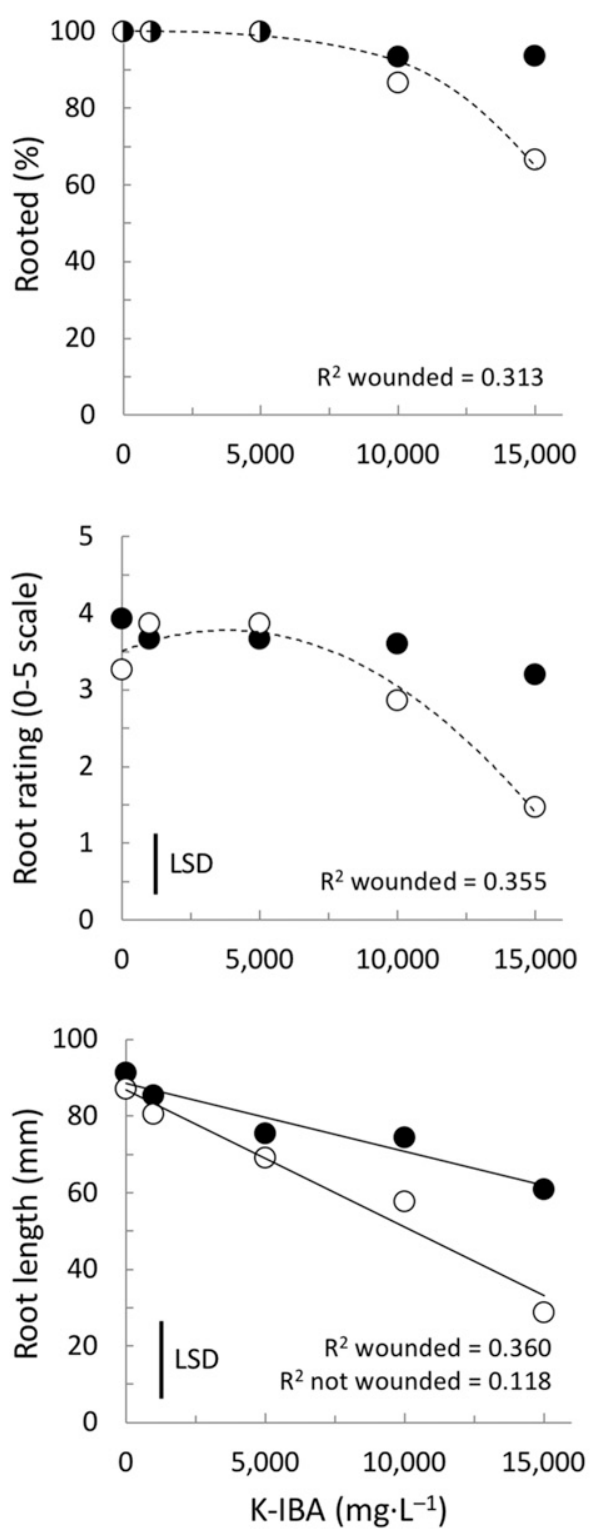

10 July 2015
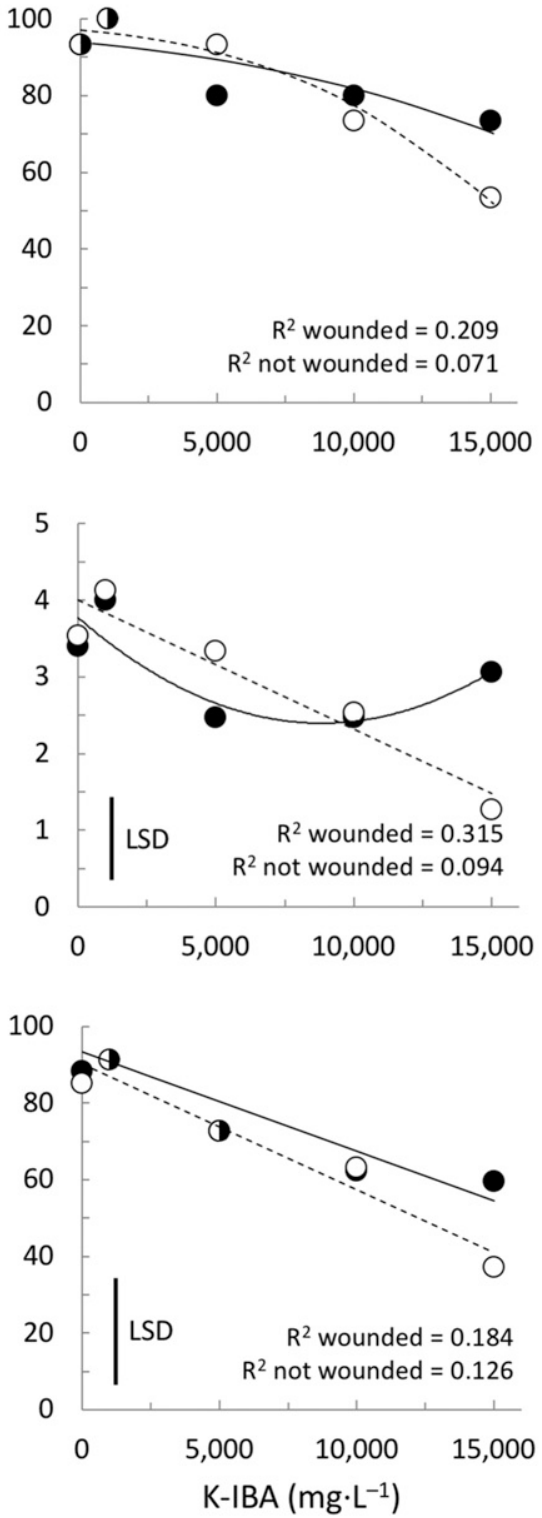

29 July 2015
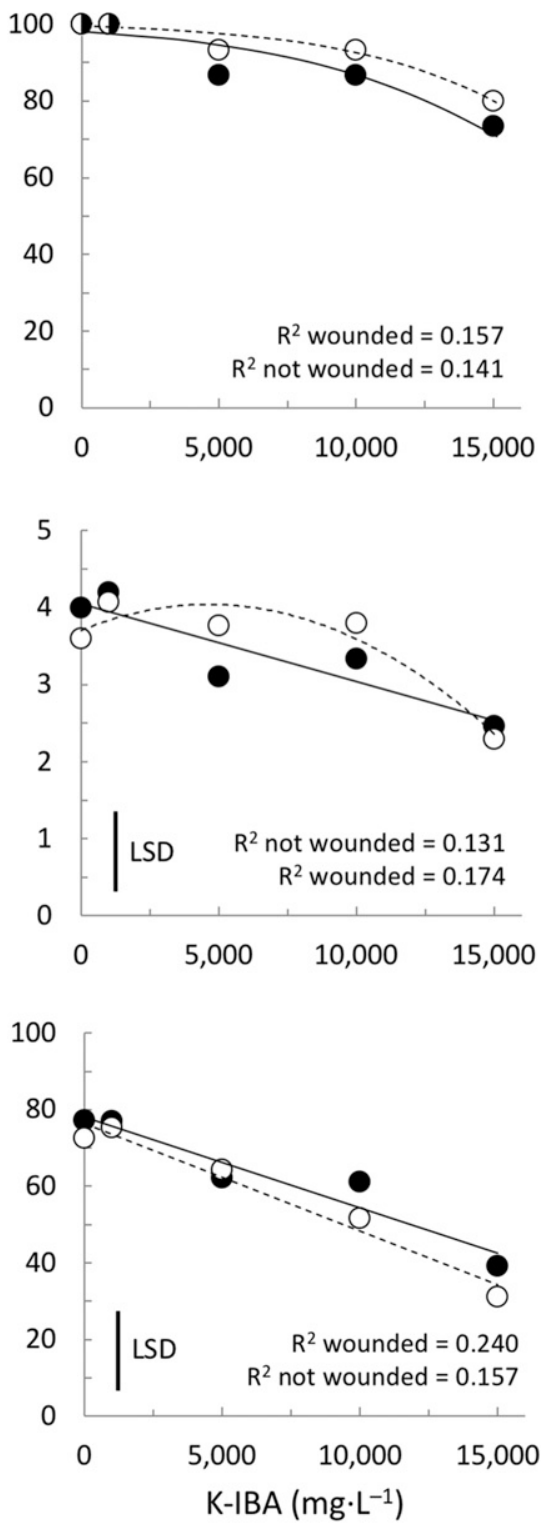

Fig. 1. Mean rooting percentages, root ratings, and root lengths of sweetgale in response to potassium salt of indole-3-butyric acid (K-IBA) concentration and wounding in 2015. Cuttings were collected on three dates to assess the success of both softwood (16 June) and semihardwood (10 July and $29 \mathrm{July}$ ) cuttings, and rooted in 3:1 perlite:peat (by volume) under intermittent mist for 10 weeks. Trend lines for rooting percentage are from logistic regression, and are shown only where the effect of K-IBA was significant. Root ratings were scored from 0 (no roots) to 5 (robust rooting). Trend lines for root rating and root length are shown where linear or quadratic terms for the effect of K-IBA concentration were significant. $R^{2}$ values, when significant, are shown for cuttings that were wounded or not wounded; values tend to be low because among-cutting variability within treatment groups was high; $1 \mathrm{mg} \cdot \mathrm{L}^{-1}=1 \mathrm{ppm}, 1 \mathrm{~mm}=0.0394$ inch. $\mathrm{LSD}=$ least significant difference.

County, ME. Stem cuttings of rhodora were collected from several dozen indigenous plants growing in a shady, wet forest in Penobscot County, ME. Cuttings of catberry were collected from eight plants growing naturally in a wet ditch in Washington County, ME.
Timing OF CUTTING COLLECTION, K-IBA CONCENTRATION, AND WOUNDING (2015). We obtained 450 stem cuttings of each species by collecting 150 cuttings on each of three dates. Cuttings of sweetgale were collected on 16 June, 10 July, and 29 July, whereas those of rhodora were collected on 11 June, 2 July, and 23 July, and those of catberry were collected on 17 June, I July, and 14 July. Cuttings collected in June were softwood in nature without terminal buds set. By the July collection dates, cuttings of the three species were semihardwood with terminal buds 
Table 1. Results of analysis of variance for root ratings and root lengths of sweetgale, rhodora, and catberry cuttings in response to potassium salt of indole3 -butyric acid (K-IBA) concentration and wounding in 2015. Cuttings of each species were collected on three dates and treated by dipping basal ends in water containing $0,1000,5000,10,000$, or $15,000 \mathrm{mg} \cdot \mathrm{L}^{-1}(\mathrm{ppm}) \mathrm{K}-\mathrm{IBA}$. All cuttings were inserted into 3:1 perlite:peat (by volume) under intermittent mist for 10 weeks. Results represent probability values significant at alpha $=0.0001\left({ }^{* *}\right)$, $0.001\left({ }^{*}\right), 0.05(*)$, or not significant (NS).

\begin{tabular}{|c|c|c|c|c|c|}
\hline Species & Collection date & Response & K-IBA concn & Wounding & Interaction \\
\hline \multirow[t]{6}{*}{ Sweetgale } & \multirow[t]{2}{*}{16 June } & Root rating & $* * *$ & ** & ** \\
\hline & & Root length & $* * *$ & ** & * \\
\hline & \multirow[t]{2}{*}{10 July } & Root rating & $* * *$ & NS & * \\
\hline & & Root length & $* * *$ & NS & NS \\
\hline & \multirow[t]{2}{*}{29 July } & Root rating & $* * *$ & NS & NS \\
\hline & & Root length & $* * *$ & NS & NS \\
\hline \multirow[t]{6}{*}{ Rhodora } & \multirow[t]{2}{*}{11 June } & Root rating & $* * *$ & $* * *$ & NS \\
\hline & & Root length & * & $* * *$ & NS \\
\hline & \multirow[t]{2}{*}{2 July } & Root rating & ** & * & NS \\
\hline & & Root length & NS & NS & NS \\
\hline & \multirow[t]{2}{*}{23 July } & Root rating & $* * *$ & NS & NS \\
\hline & & Root length & $* * *$ & NS & * \\
\hline \multirow[t]{6}{*}{ Catberry } & \multirow[t]{2}{*}{17 June } & Root rating & NS & NS & * \\
\hline & & Root length & NS & NS & $*$ \\
\hline & \multirow[t]{2}{*}{ I July } & Root rating & NS & NS & NS \\
\hline & & Root length & NS & NS & NS \\
\hline & \multirow[t]{2}{*}{14 July } & Root rating & $* *$ & NS & * \\
\hline & & Root length & * & NS & NS \\
\hline
\end{tabular}

set. Cuttings of sweetgale had 8 to 12 nodes and ranged from 9.5 to 11.0 $\mathrm{cm}$ long, cuttings of rhodora had 10 to 15 nodes and ranged from 8.5 to $10.5 \mathrm{~cm}$ long, and cuttings of catberry had three to five nodes and ranged from 6.0 to $9.5 \mathrm{~cm}$ long. Leaves were removed from the basal $l$ inch of stem before treatments were applied.

Cuttings were either unwounded or wounded on one side by scraping with a razor blade until xylem was exposed in a $2-\mathrm{cm} \times 2$-mm vertical strip along one side of the stem, and dipped for $5 \mathrm{~s}$ in water or 1000,5000 , 10,000 , or $15,000 \mathrm{mg} \cdot \mathrm{L}^{-1} \mathrm{~K}-\mathrm{IBA}$ dissolved in water. On each date, 15 replicate cuttings were treated with each combination of wounding and K-IBA concentration. All cuttings were prepared and stuck on the day of collection into 50 -cell vacuum propagation sheets (Dillen-ITML, Middlefield, $\mathrm{OH}$ ) filled with a premoistened substrate of 3:1 (by volume) super coarse horticultural perlite (Whittemore Co., Lawrence, MA) and milled peatmoss (Sun Gro Horticulture, Agawam, MA). Propagation sheets were inserted into 1020 trays $(21.0 \times 10.75$ $\times 2.5$ inches) with a separate completely randomized design for each combination of species and collection date, with individual cuttings serving as the experimental units $(\mathrm{n}=15 ; \mathrm{N}=150$ for each species on each date). Flats were placed under an intermittent mist system outfitted with inverted mist nozzles (VibroNet Green Sprinklers; Netafim USA, Fresno, CA) that provided $8 \mathrm{~s}$ of mist every $10 \mathrm{~min}$. Natural solar radiation in the glass-glazed greenhouse was reduced with white shade compound on the glass and a frame over the bench draped with $25 \%$ mylar shadecloth. The air temperature in the greenhouse was measured using a data logger (EL-USB-2-LCD; Lascar Electronics, Erie, PA) and averaged $21.6^{\circ} \mathrm{C}$. Photosynthetically active radiation $(P A R)$ at solar noon ranged from 400 to 980 $\mu \mathrm{mol} \cdot \mathrm{m}^{-2} \cdot \mathrm{s}^{-1}$ and relative humidity ranged from $41 \%$ to $94 \%$.

We harvested each batch of cuttings 10 weeks after sticking them, and counted the number of cuttings that rooted, assigned subjective root ratings, and measured the length of the longest root on each cutting. A cutting was considered rooted if it had at least one root longer than $3 \mathrm{~mm}$. We assigned subjective ratings for root system quality on a scale from 0 to 5 , with " 0 " for no roots, " 1 " for one to several roots (not transplantable), "2" for a lopsided and/or weakly developed root system, "3" for a moderately developed root system, "4" for a well-developed root system, and " 5 " for an extensive root system symmetrically distributed around each cutting and extending, at minimum, to the edges of the propagation cell. For each collection date, results were analyzed to determine the effect of wounding and $\mathrm{K}$ IBA concentration on measures of rooting. Collection date was not analyzed as a treatment factor, because cuttings from each date were technically pseudoreplicates in this context, as they were collected from one place and time, handled and treated as a group, and stuck under mist as a group. Nonetheless, results from different cutting collection times can demonstrate the potential for root formation over a range of dates.

K-IBA CONCENTRATION AND SUBSTRATE COMPOSITION (2016). Cuttings of all three species were handled, treated with K-IBA, and placed under mist in the same way as described for 2015 . We collected 360 cuttings of catberry on 2 July and 270 cuttings each of sweetgale and rhodora on 18 and 24 July, respectively. Cuttings of all three species were semihardwood in nature, with terminal buds that were set for the season. Cuttings of sweetgale had 10 to 13 nodes and ranged from 10.0 to 10.5 $\mathrm{cm}$ long, cuttings of rhodora had 10 to 14 nodes and ranged from 9.5 to $10.0 \mathrm{~cm}$ long, and cuttings of catberry had four to five nodes and ranged from 7.5 to $8.0 \mathrm{~cm}$ long. Leaves were stripped from the basal $\mathrm{l}$ inch of stem and every cutting was wounded as described for 2015 . The basal end of each cutting was dipped for $5 \mathrm{~s}$ into water with $0,1000,5000$, 10,000 , or $15,000 \mathrm{mg} \cdot \mathrm{L}^{-1} \mathrm{~K}-\mathrm{IBA}$ and inserted into a substrate of $100 \%, 75 \%$, or $50 \%$ perlite, with the remaining volume occupied by peatmoss. Substrate components were of the same grade, and from the same suppliers, as those in 2015. Cuttings of each species were arranged in a separate completely randomized experiment with individual cuttings serving as experimental units. For sweetgale and rhodora, 18 replicates were included per combination of K-IBA treatment and substrate ( $\mathrm{n}=18 ; \mathrm{N}=270$ for each species). Twenty-four replicates of catberry were assigned to each treatment combination to improve estimates of treatment effects $(\mathrm{n}=24 ; \mathrm{N}=360)$. 

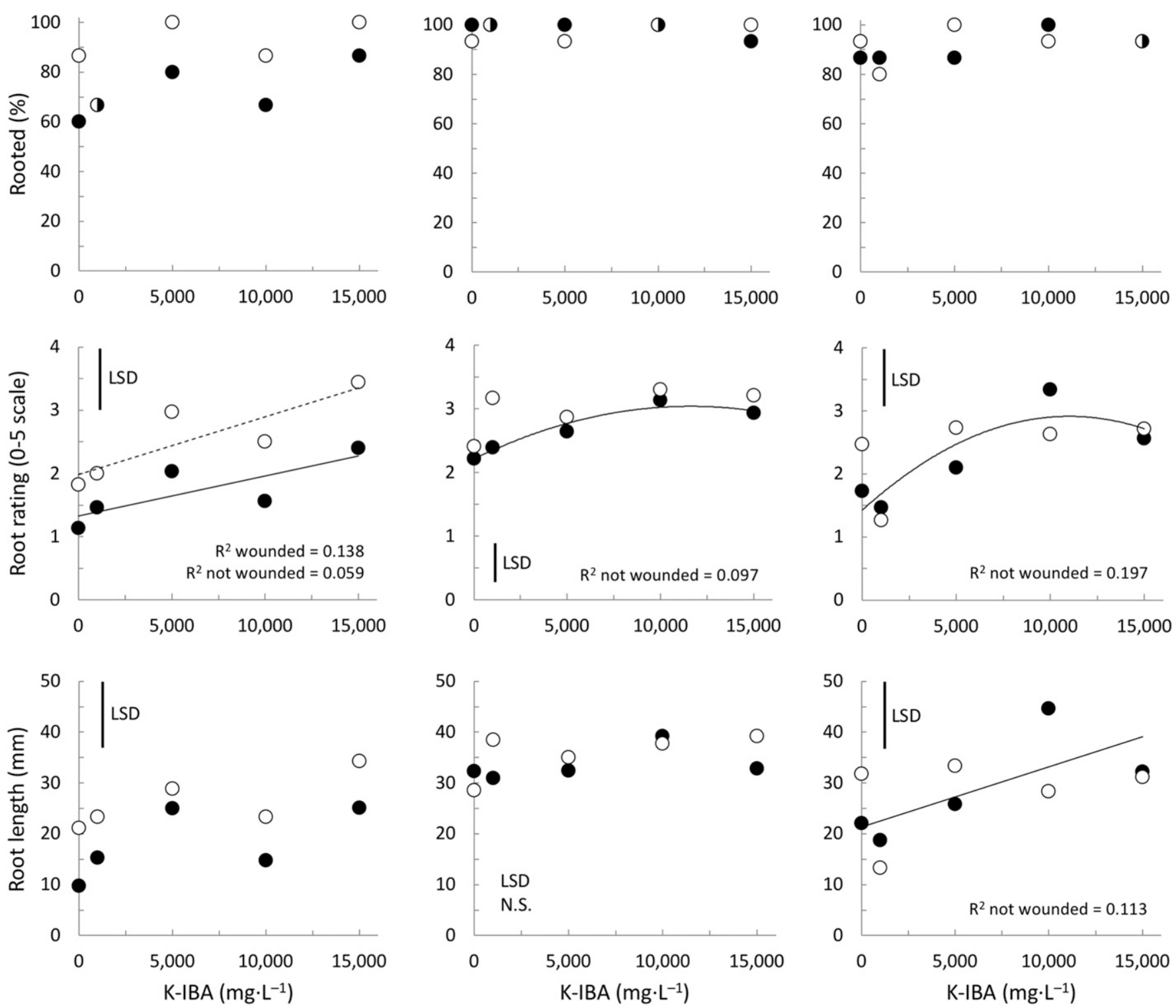

Fig. 2. Mean rooting percentages, root ratings, and root lengths of rhodora in response to potassium salt of indole-3-butyric acid (K-IBA) concentration and wounding in 2015. Cuttings were collected on three dates to assess the success of both softwood (11 June) and semihardwood (2 July and 23 July) cuttings, and rooted in 3:1 perlite:peat (by volume) under intermittent mist for 10 weeks. Trend lines are absent for rooting percentage because logistic regression showed no effect of $\mathrm{K}$ IBA. Root ratings were scored from 0 (no roots) to 5 (robust rooting). Trend lines for root rating and root length are shown where linear or quadratic terms for the effect of K-IBA concentration were significant. $R^{2}$ values, when significant, are shown for cuttings that were wounded or not wounded; values tend to be low because among-cutting variability within treatment groups was high. Least significant difference (LSD) is shown if the analysis of variance was significant; $1 \mathrm{mg} \cdot \mathrm{L}^{-1}=1 \mathrm{ppm}$, $1 \mathrm{~mm}=0.0394$ inch .

Air temperature over the mist bench was logged in 2016 using a microstation with radiation shield (Watchdog 1450; Spectrum Technologies, Aurora, IL) located under the shadecloth near the height of the cuttings. The temperature averaged $25.2^{\circ} \mathrm{C}$, with a maximum instantaneous temperature of $37.7^{\circ} \mathrm{C}$. The same datalogger with a quantum light sensor recorded $P A R$ under the shadecloth once every $10 \mathrm{~min}$, and daily light integral (DLI) was calculated from these data. The average DLI was $7.29 \mathrm{~mol} \cdot \mathrm{m}^{-2} \cdot \mathrm{d}^{-1}$ with a maximum instantaneous $P A R$ reading of
$675 \mu \mathrm{mol} \cdot \mathrm{m}^{-2} \cdot \mathrm{s}^{-1}$. Substrate porosities were characterized as described in Hayes and Peterson (2019). Average aeration porosities were $28.5 \%, 24.4 \%$, and $21.6 \%$ and average water-holding capacities were $44.5 \%, 48.1 \%$, and $52.5 \%$ for media of $100 \%, 75 \%$, and $50 \%$ perlite, respectively. 
17 June 2015
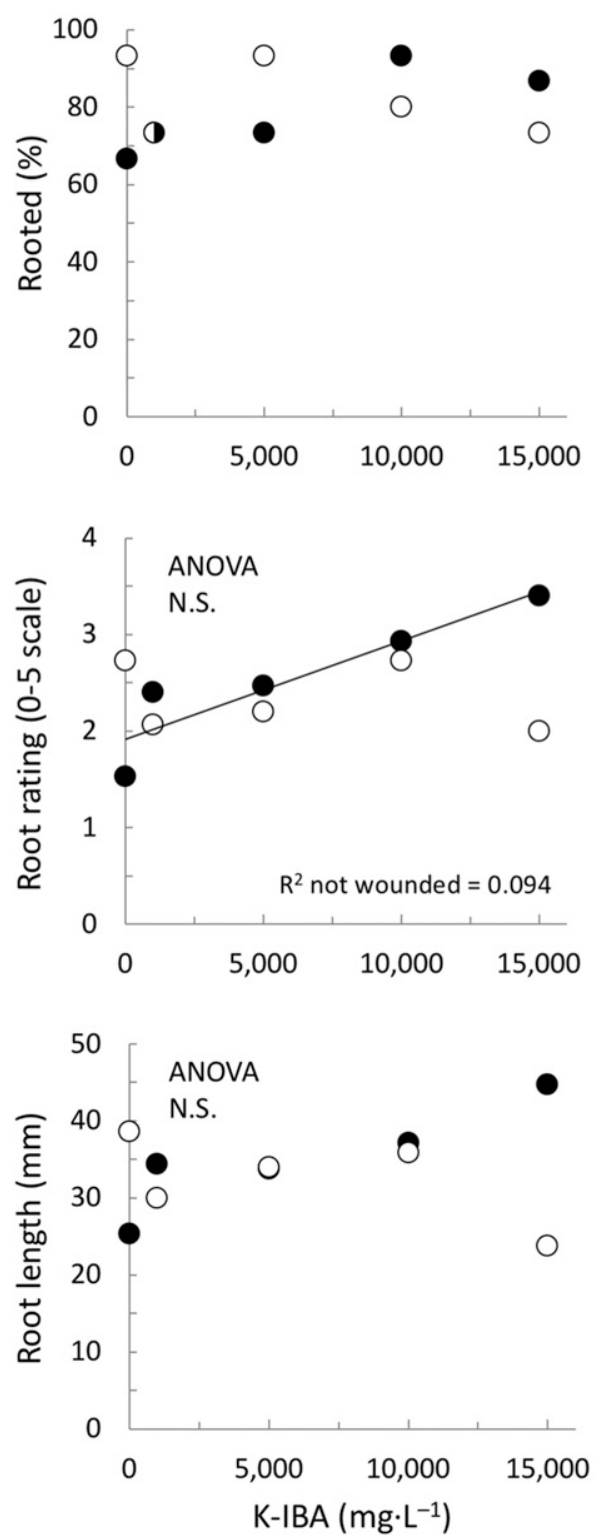

1 July 2015

14 July 2015
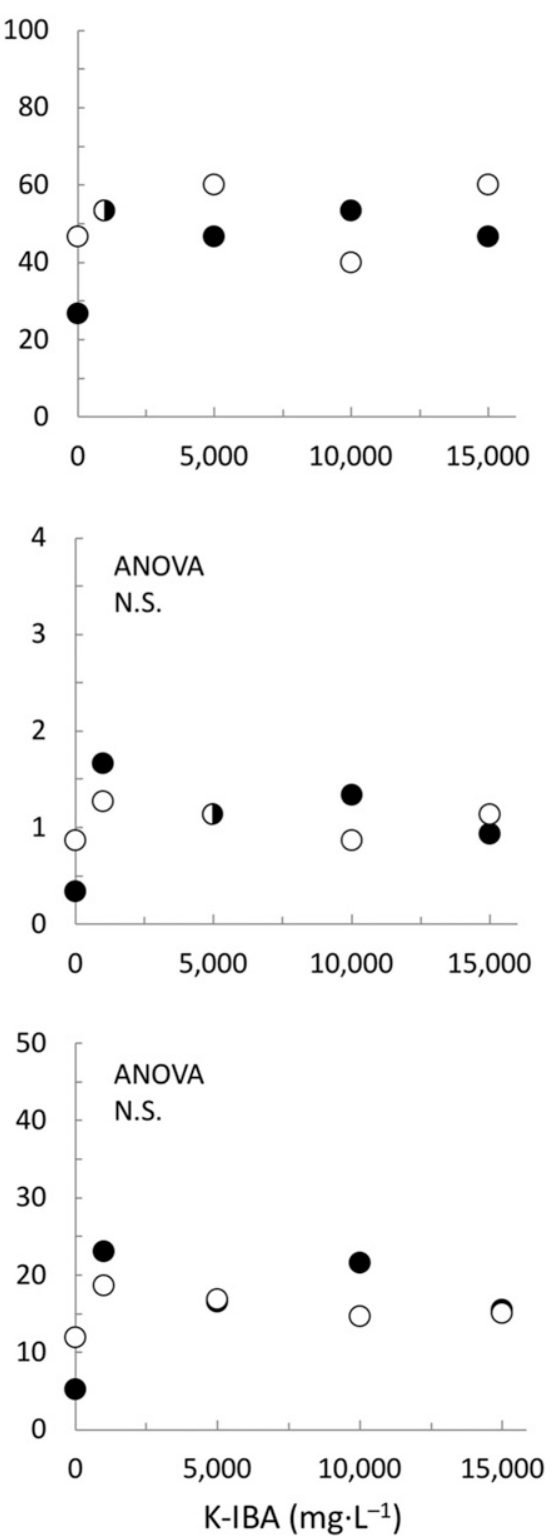
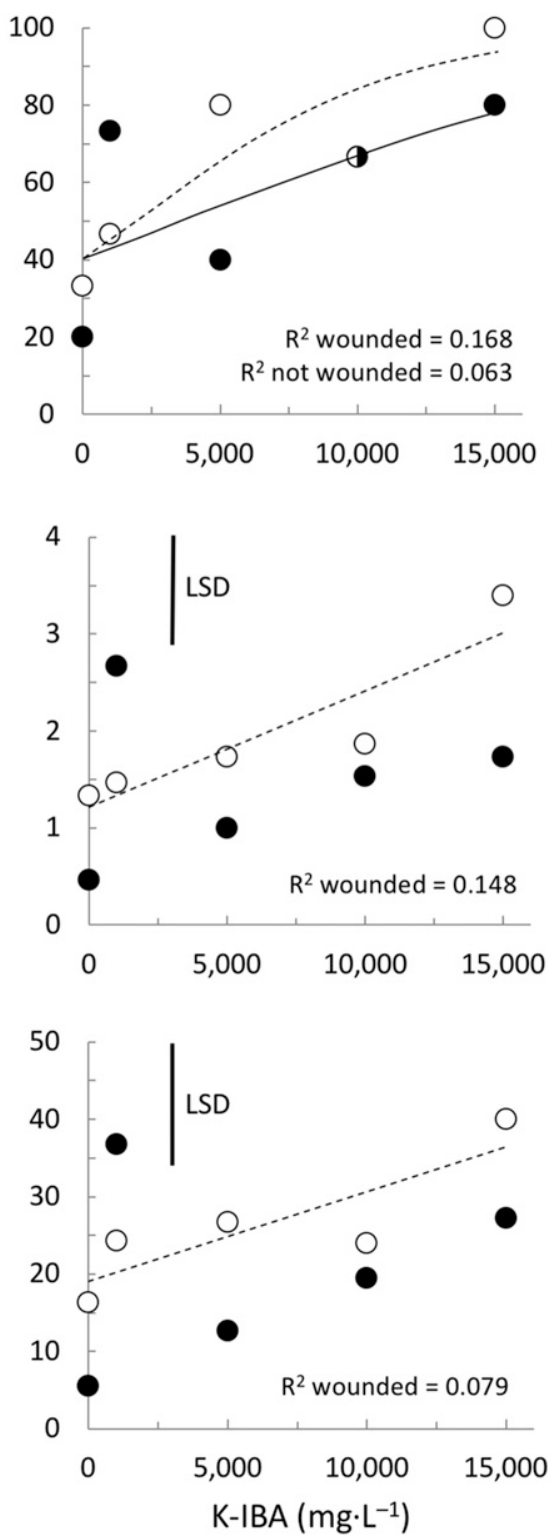

Fig. 3. Mean rooting percentages, root ratings, and root lengths of catberry in response to potassium salt of indole-3-butyric acid (K-IBA) concentration and wounding in 2015. Cuttings were collected on three dates to assess the success of both softwood (17 June) and semihardwood (1 July and $14 \mathrm{July}$ ) cuttings, and rooted in 3:1 perlite:peat (by volume) under intermittent mist for 10 weeks. Trend lines for rooting percentage are from logistic regression, and are shown only where the effect of K-IBA was significant. Root ratings were scored from 0 (no roots) to 5 (robust rooting). Trend lines for root rating and root length are shown where linear or quadratic terms for the effect of K-IBA concentration were significant. $R^{2}$ values, when significant, are shown for cuttings that were wounded or not wounded; values tend to be low because among-cutting variability within treatment groups was high. Least significant difference (LSD) is shown if the analysis of variance (ANOVA) was significant; $1 \mathrm{mg} \cdot \mathrm{L}^{-1}=1 \mathrm{ppm}, 1 \mathrm{~mm}=0.0394$ inch.

We harvested cuttings of sweetgale, rhodora, and catberry on 2,18 , and 24 Sept., respectively, after each was under mist for 8 weeks. We counted the number of cuttings that rooted, assigned subjective root ratings as described for 2015, and measured the length of the longest root on each cutting. Root dry weights were recorded after removing root systems from each cutting, placing them into folded paper towels, and drying them for $3 \mathrm{~d}$ in a drying room heated to $69^{\circ} \mathrm{C}$.
Data Analysis. For each experiment over both study years, the percentage of cuttings that rooted was assessed by logistic regression in JMP 14.1.0 (SAS Institute, Cary, NC) because the influence of independent variables on the probability 


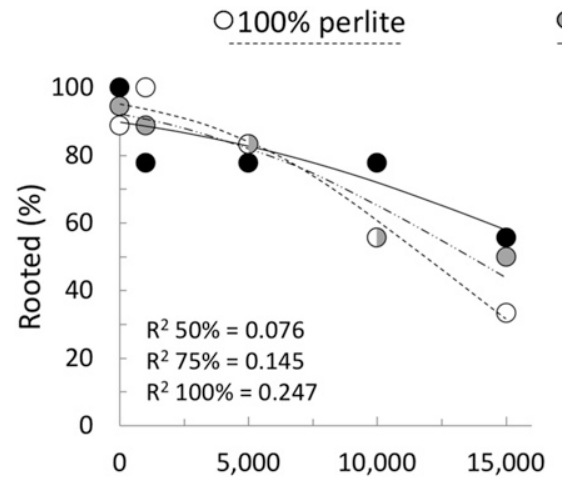

O $75 \%$ perlite

$50 \%$ perlite
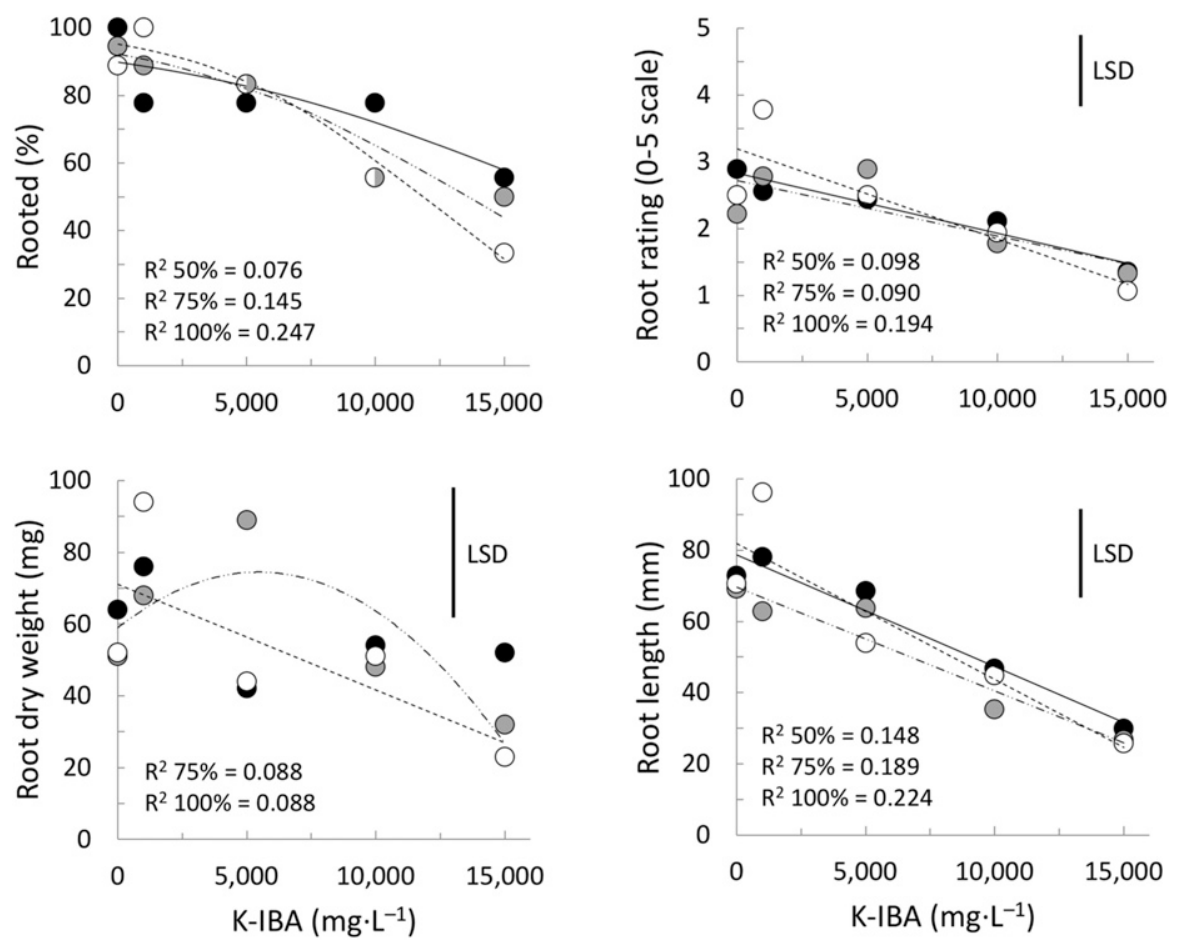

Fig. 4. Mean rooting percentages, root ratings, root dry weights, and root lengths of sweetgale in response to potassium salt of indole-3-butyric acid (K-IBA) concentration and perlite-to-peat composition of substrates in 2016. Substrates were $100 \%, 75 \%$, or $50 \%$ perlite, with the remaining volume occupied by peat. Cuttings were rooted under intermittent mist for 8 weeks. Root ratings were scored from 0 (no roots) to 5 (robust rooting). Trend lines for rooting percentage are from logistic regression, and are shown only where the effect of K-IBA was significant. Trend lines for root rating, root dry weight, and root length are shown where linear or quadratic terms for the effect of K-IBA concentration were significant. $R^{2}$ values, when significant, are shown for cuttings in $100 \%, 75 \%$, and $50 \%$ perlite; values tend to be low because among-cutting variability within treatment groups was high; $1 \mathrm{mg} \cdot \mathrm{L}^{-1}=1 \mathrm{ppm}, 1 \mathrm{mg}=3.5274 \times 10^{-5} \mathrm{oz} . \mathrm{LSD}=$ least significant difference.

Table 2. Results of analysis of variance for root ratings and root lengths of sweetgale, rhodora, and catberry cuttings in response to potassium salt of indole3 -butyric acid (K-IBA) concentration and substrate composition in 2016.

Cuttings were treated by dipping basal ends in water containing $0,1000,5000$, 10,000 , or $15,000 \mathrm{mg} \cdot \mathrm{L}^{-1}(\mathrm{ppm}) \mathrm{K}-\mathrm{IBA}$, and inserted into substrates of $100 \%$, $75 \%$, or $50 \%$ perlite, with the remaining volume occupied by peat. All cuttings were placed under intermittent mist for 8 weeks. Results represent probability values significant at alpha $=0.0001(* * *), 0.001(* *)$, or not significant (NS).

\begin{tabular}{llccc}
\hline Species & \multicolumn{1}{c}{ Response } & $\begin{array}{c}\text { K-IBA } \\
\text { concn }\end{array}$ & $\begin{array}{c}\text { Substrate } \\
\text { composition }\end{array}$ & Interaction \\
\hline Sweetgale & Root rating & $* * *$ & NS & NS \\
& Root length & $* * *$ & NS & NS \\
Rhodora & Root dry weight & $* *$ & NS & NS \\
& Root rating & $* * *$ & $* * *$ & NS \\
& Root length & $* *$ & $* * *$ & NS \\
Catberry & Root dry weight & $* * *$ & $* * *$ & NS \\
& Root rating & $* * *$ & $* * *$ & NS \\
& Root length & $* * *$ & $* * *$ & $* *$ \\
\hline
\end{tabular}

of binary responses is not suited to analysis of variance (ANOVA). Fisher's exact test was used to determine whether wounding influenced the probability of rooting. The main effects and interactions for all other dependent variables were evaluated by two-way ANOVA in JMP 14.1.0. Specific rooting responses were characterized using two methods, which included testing the significance of linear and quadratic terms for responses to $\mathrm{K}$ IBA concentrations, and separating means by Fisher's protected least significant difference to permit comparisons of specific treatment combinations.

\section{Results}

Timing of CUtTING COLlection, K-IBA CONCENTRATION, AND WOUNDING (2015). For every collection date, sweetgale cuttings showed a trend of decreasing rooting percentages with increasing K-IBA concentration (Fig. 1), but wounding did not affect rooting percentage. Sweetgale root ratings averaged 4 when 0 or 1000 $\mathrm{mg} \cdot \mathrm{L}^{-1} \mathrm{~K}-\mathrm{IBA}$ was applied, regardless of collection date, and decreased with increasing auxin application. A similar trend was evident for root length (Fig. 1). Wounding was not essential for adequate rooting (Table 1 ), and cuttings from the first two collection dates that were wounded before they were treated with $15,000 \mathrm{mg} \cdot \mathrm{L}^{-1}$ $\mathrm{K}-\mathrm{IBA}$ had lower root ratings than their unwounded counterparts (Fig. 1). Likewise, root lengths among wounded cuttings from the first collection date that received $15,000 \mathrm{mg} \cdot \mathrm{L}^{-1} \mathrm{~K}-\mathrm{IBA}$ were diminished.

The rooting percentage of rhodora cuttings ranged from $60 \%$ to $100 \%$ on 11 June, and from $80 \%$ to $100 \%$ on subsequent collection dates, with no relationship between K-IBA concentration and rooting percentage (Fig. 2). Fisher's exact tests showed that wounding increased rooting percentages for cuttings collected on 11 June, but not on 2 July or 23 July. K-IBA concentration produced inconsistent effects on root ratings and root lengths (Fig. 2). Wounding likewise had an inconsistent effect on rooting responses (Table 1 ).

Rooting of catberry was variable in 2015. Percentage rooting and measures of root system quality were low on the second collection date 
compared with the first and third dates (Fig. 3). Rooting percentage of cuttings collected on 17 June and 1 July was not related to K-IBA concentration, whereas rooting percentage increased with K-IBA concentration among cuttings collected on 14 July (Fig. 3). Fisher's exact test showed no effect of wounding on rooting percentage for any collection date. Although we found no differences in root ratings or root lengths for the first two collection dates (Table 1), root rating increased linearly with increasing K-IBA concentration among unwounded cuttings collected on the first date (Fig. 3). Wounding did not significantly affect root ratings or root lengths, but interactions occurred between wounding and K-IBA concentration (Table 1). Among cuttings collected on the third date, increasing the K-IBA concentration increased root ratings and root lengths of wounded cuttings, but the trend was less consistent for unwounded cuttings (Fig. 3).

K-IBA CONCENTRATION AND SUBSTRATE COMPOSITION (2016). As in the previous year, the percentage of sweetgale cuttings that rooted decreased as K-IBA concentration increased, from a high of $100 \%$ with no K-IBA to less than $60 \%$ among cuttings receiving $15,000 \mathrm{mg} \cdot \mathrm{L}^{-1} \mathrm{~K}-\mathrm{IBA}$ (Fig. 4). Fisher's exact test showed no effect of substrate composition on rooting percentage. K-IBA concentration, but not substrate, affected measurements of root system quality (Table 2). Regardless of substrate composition, the root ratings, root lengths, and root dry weights were generally greatest when K-IBA concentrations of 0 or $1000 \mathrm{mg} \cdot \mathrm{L}^{-1} \mathrm{~K}-\mathrm{IBA}$ were applied (Fig. 4).

Rhodora cuttings rooted at high percentages $(80 \%$ to $100 \%)$ in 2016 , regardless of K-IBA concentration, when $25 \%$ or $50 \%$ peat was included in the medium (Fig. 5). When the cuttings were inserted into a substrate of $100 \%$ perlite, the highest K-IBA concentrations were required to increase rooting to $80 \%$. Substrate and K-IBA concentration also affected measurements of root system quality (Table 2). When peatmoss was included in the substrate, K-IBA concentrations of 5000 or $10,000 \mathrm{mg} \cdot \mathrm{L}^{-1}$ produced double the root ratings and root lengths of auxin-free controls, and produced root dry weights more

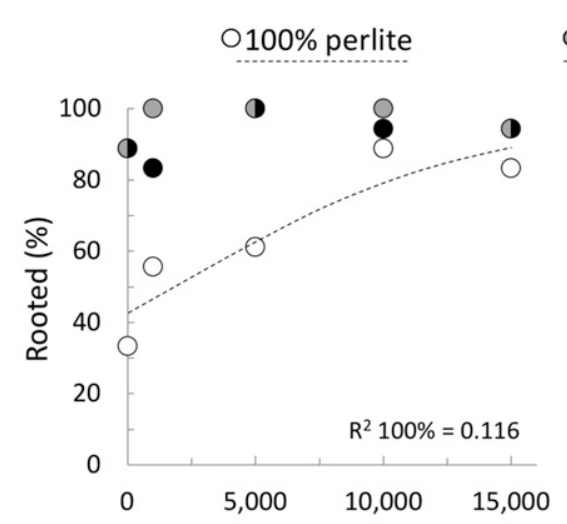

0 $75 \%$ perlite $\quad$-50\% perlite
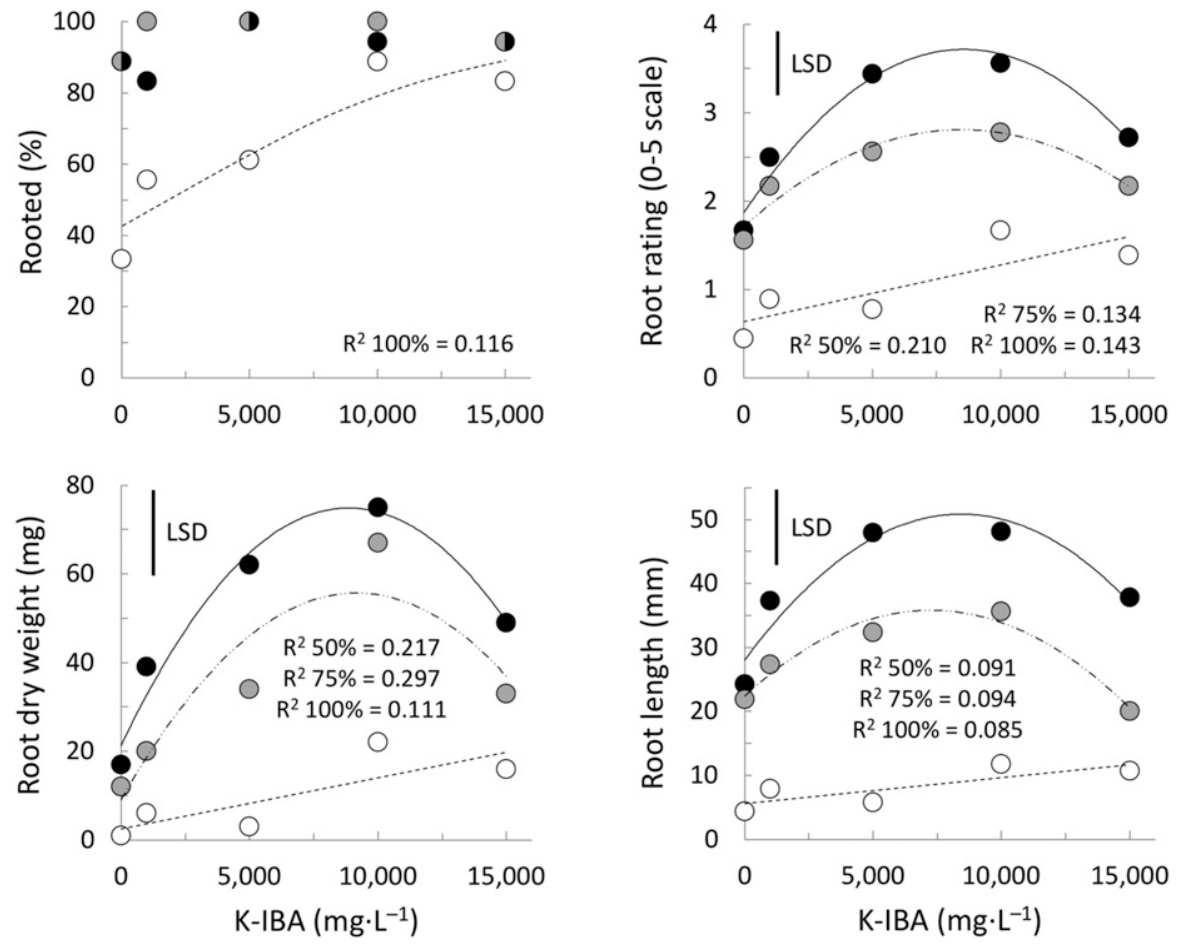

Fig. 5. Mean rooting percentages, root ratings, root dry weights, and root lengths of rhodora in response to potassium salt of indole-3-butyric acid (K-IBA) concentration and perlite-to-peat composition of substrates in 2016. Substrates were $100 \%, 75 \%$, or $50 \%$ perlite, with the remaining volume occupied by peat. Cuttings were rooted under intermittent mist for 8 weeks. Root ratings were scored from 0 (no roots) to 5 (robust rooting). Trend lines for rooting percentage are from logistic regression, and are shown only where the effect of K-IBA was significant. Trend lines for root rating, root dry weight, and root length are shown where linear or quadratic terms for the effect of K-IBA concentration were significant. $R^{2}$ values, when significant, are shown for cuttings in $100 \%, 75 \%$, and $\mathbf{5 0} \%$ perlite; values tend to be low because among-cutting variability within treatment groups was high; $1 \mathrm{mg} \cdot \mathrm{L}^{-1}=1 \mathrm{ppm}, 1 \mathrm{mg}=3.5274 \times 10^{-5} \mathrm{oz} . \mathrm{LSD}=$ least significant difference.

than four times as great (Fig. 5). Cuttings inserted into $100 \%$ perlite produced strikingly inferior root ratings, root dry weights, and root lengths.

Rooting of catberry was significantly influenced by substrate composition in 2016 , with $50 \%$ and $75 \%$ perlite producing nearly identical rooting percentages, whereas perlite alone produced vastly inferior rooting characterized by proliferation of excessive callus (Fig. 6). The proportion of cuttings that rooted increased when K-IBA concentration increased. Substrate and K-IBA concentration also affected measurements of root system quality (Table 2 ). Root ratings, root lengths, and root dry weights responded linearly or quadratically to K-IBA concentration, with predicted response maxima between 5000 and $15,000 \mathrm{mg} \cdot \mathrm{L}^{-1}$ K-IBA regardless of substrate (Fig. $6)$. Substrates of $1: 1$ perlite:peat consistently produced the greatest measures of rooting.

\section{Discussion}

Sweetgale, rhodora, and catberry differ markedly in their responses to K-IBA concentration and substrate composition, but the three species can be rooted from softwood or semihardwood cuttings and wounding is not essential. In general, species-specific responses to propagation treatments are not surprising. For example, Cartabiano and Lubell (2013) found that trends in rooting percentage and measures of root system quality varied among four native shrubs in response to K-IBA concentration. In our study, applied KIBA consistently produced an inhibitory 


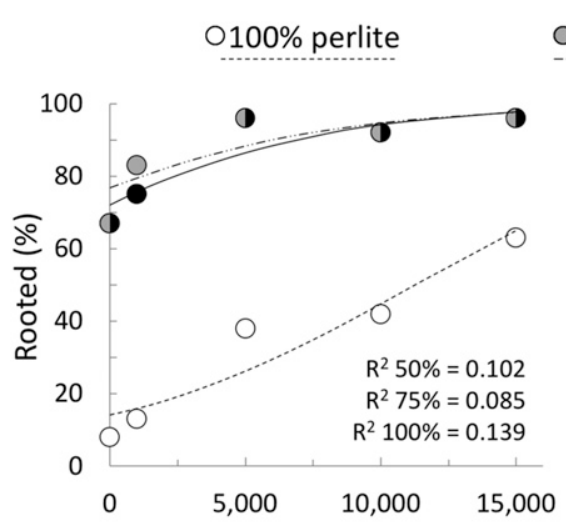

0 75\% perlite $\quad$-50\% perlite
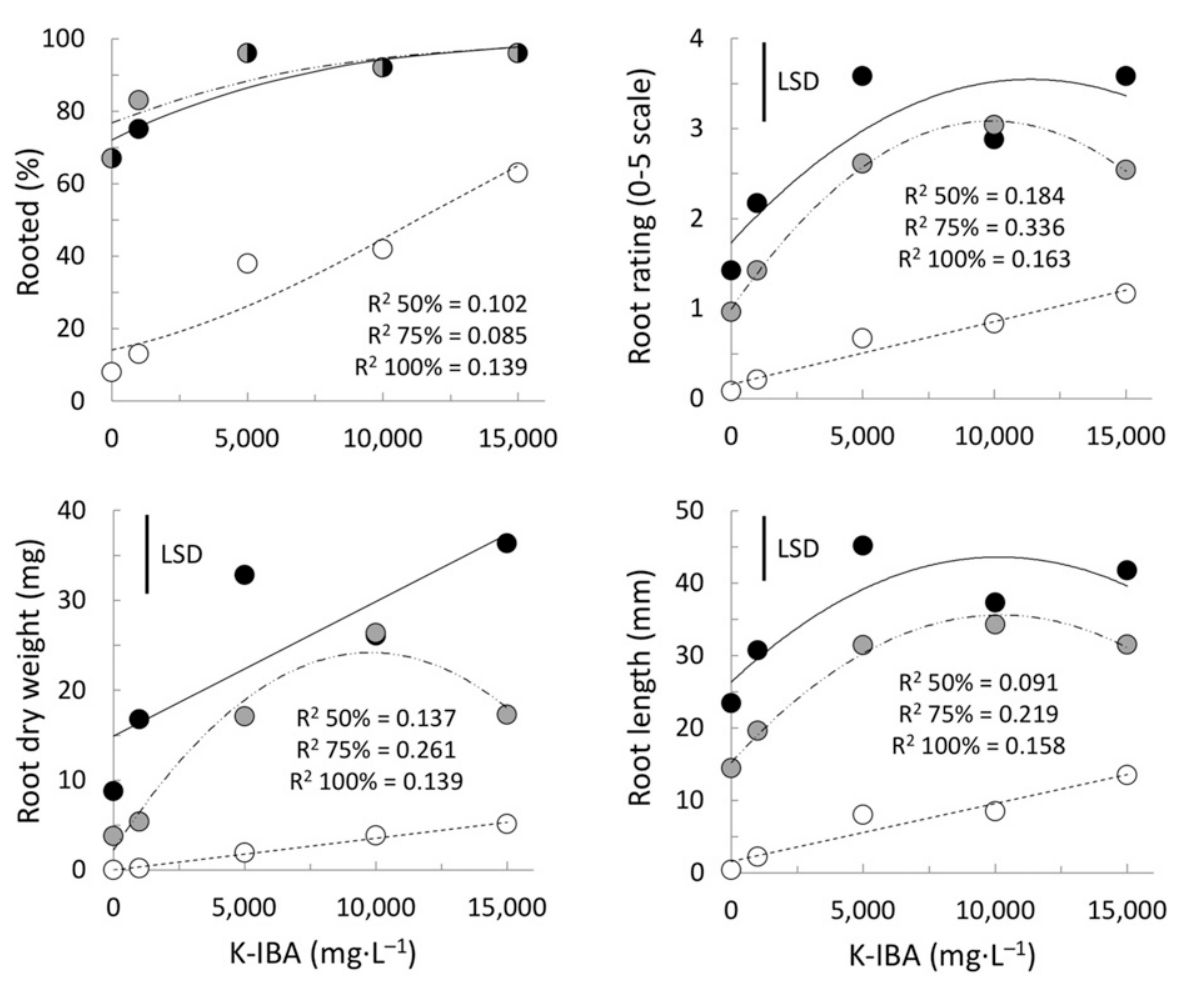

Fig. 6. Mean rooting percentages, root ratings, root dry weights, and root lengths of catberry in response to potassium salt of indole-3-butyric acid (K-IBA) concentration and perlite-to-peat composition of substrates in 2016. Substrates were $100 \%, 75 \%$, or $50 \%$ perlite, with the remaining volume occupied by peat. Cuttings were rooted under intermittent mist for 8 weeks. Root ratings were scored from 0 (no roots) to 5 (robust rooting). Trend lines for rooting percentage are from logistic regression, and are shown only where the effect of K-IBA was significant. Trend lines for root rating, root dry weight, and root length are shown where linear or quadratic terms for the effect of K-IBA concentration were significant. $R^{2}$ values, when significant, are shown for cuttings in $100 \%, 75 \%$, and $\mathbf{5 0} \%$ perlite; values tend to be low because among-cutting variability within treatment groups was high; $1 \mathrm{mg} \cdot \mathrm{L}^{-1}=1 \mathrm{ppm}, 1 \mathrm{mg}=3.5274 \times 10^{-5} \mathrm{oz} . \mathrm{LSD}=$ least significant difference.

effect on rooting of sweetgale (Figs. 1 and 4). In contrast, rhodora and catberry responded positively to applied KIBA (Figs. 2, 3, 5, and 6).

Because all three species are found frequently in bogs of New England, we speculated that adding peatmoss to the propagation substrate would improve measures of rooting; however, species responses to propagation substrates were not consistent, as sweetgale was insensitive to substrate (Table 2) but rhodora and catberry benefited from the inclusion of peatmoss (Figs. 5 and 6). Catberry consistently produced a large mass of callus, and few roots, when the substrate was perlite alone. Contrary to our findings, semihardwood cuttings of mountain fly honeysuckle (Lonicera villosa) produced greater root dry weights and root system volumes in $100 \%$ perlite than in substrates with less perlite (Hayes and Peterson, 2019). It is unclear why mountain fly honeysuckle and the three species we investigated in this study, all of which co-occur in wetland habitats with organic root zones, responded differently to substrate composition within the same overhead mist system. Physiological differences among species or among cuttings collected at different stages of development could dictate how sensitive a crop is to substrate composition. Generally, the beneficial effect of peatmoss in a propagation substrate may be attributed to an increase in substrate water-holding capacity, although aeration porosity decreases as a consequence (Hartmann et al., 2011).
Although our work demonstrates that vegetative propagation of sweetgale, rhodora, and catberry is commercially feasible, successful commercialization of new crops also requires an understanding of landscape adaptability. Lubell (2013) showed the high suitability of sweetgale to soils drier than those found in native habitats, which suggests that sweetgale could make a viable nursery crop that is reliably propagated from stem cuttings. Native species like sweetgale could therefore be used more broadly in a variety of landscape settings to replace nonnative, invasive species in plant palettes (Lubell, 2013). The commercial potential of rhodora and catberry is less well understood, because the performance of these plants in challenging landscape conditions has not been reported.

In summary, we found that stem cuttings of sweetgale, rhodora, and catberry can be successfully rooted across a range of dates while cuttings are softwood to semihardwood in nature. Sweetgale does not respond favorably to increasing concentrations of K-IBA, a finding that was consistent between years. Cuttings rooted at high percentages $(>80 \%)$ and produced highquality root systems with or without peatmoss in the propagation substrate. In contrast, rhodora and catberry produced robust root systems when treated with 5000 to $10,000 \mathrm{mg} \cdot \mathrm{L}^{-1} \mathrm{~K}-\mathrm{IBA}$ and rooted in substrates containing $25 \%$ to $50 \%$ peatmoss. Wounding was not essential for successful root formation in any species, although it was not detrimental and sometimes improved measures of root system quality.

\section{Literature cited}

Cartabiano, J.A. and J.D. Lubell. 2013. Propagation of four underused native species from softwood cuttings. HortScience 48:1018-1020.

Gardner, J.A.G., J.D. Lubell, and M.H. Brand. 2019. Propagation of Comptonia peregrina L. from stem cuttings. HortScience 54:511-513.

Hartmann, H.T., D.E. Kester, F.T. Davies, and R.L. Geneve. 2011. Hartmann and Kester's plant propagation: Principles and practices. 8th ed. Prentice Hall, Upper Saddle River, NJ.

Hayes, D.J. and B.J. Peterson. 2019. Vegetative propagation of mountain fly honeysuckle (Lonicera villosa) by overhead mist and subirrigation. HortScience 54:916-919. 
Norris, K.D. 2011. Horticultural \& ecophysiological evaluations of leatherwoods (Dirca spp.). Iowa State Univ., Ames, MS Thesis.

Lubell, J.D. and M.H. Brand. 2011. Propagation medium influences success of sweet fern [Comptonia peregrina (L.)
Coult.] rhizome cuttings. Propag. Ornam. Plants 11:47-49.

Lubell, J.D. 2013. Evaluating landscape performance of six native shrubs as alternatives to invasive exotics. HortTechnology 23:119-125.
Still, S.M. and S. Zanon. 1991. Effects of $\mathrm{K}$-IBA rates and timing on rooting percentage and root quality of Amelanchier laevis. J. Environ. Hort. 9:86-88. 